\title{
DIVERSITY OF THE TSI INDICATORS OF THE MIDDLE-FOREST SMALL RETENTION RESERVOIR
}

\author{
Joanna Szczykowska' ${ }^{1}$ Anna Siemieniuk' ${ }^{1}$, Józefa Wiater ${ }^{1}$ \\ 1 Department of Technology in Engineering and Environmental Protection, Bialystok University of Technology, \\ ul.Wiejska 45E, 15-351 Białystok, Poland, e-mail: j.szczykowska@pb.edu.pl; a.siemieniuk@pb.edu.pl
}

Received: 2015.08 .15 Accepted: 2015.10.06 Published: 2015.11.10

\begin{abstract}
Studies upon the trophic status were carried out using water samples from a small retention reservoir Topiło located in a particularly valuable natural forests of Puszcza Białowieska. In order to assess the degree of Topiło reservoir contamination, three measurement and control points were selected for testing, which were situated near the inflow (point No. 1) and outflow (point No. 3) of river Perebel, as well as in the middle part of the reservoir (point No. 2). The selection and placement of measurement and control points on the reservoir was dictated by the ability to capture changes in the study object. Tests of water samples collected from the surface layer of the coastal zone, were carried out once a month during the period from April 2007 to March 2014. The following determinations in collected water samples were performed: total nitrogen, total phosphorus, chlorophyll "a", and turbidity. The trophic level of Topiło reservoir was also assessed according to the concentration criteria and based on the trophic status indices (TSI) calculated after Carlson's as well as Kratzer and Brezonik's. Given the annual average value of overall trophic level (Trophic Status Index), the dominant role of the TSI (TP) during all years of research attracts some attention. The TSI index values ranged within 78.3-80.26, which allowed to classify the water of Topiło reservoir as hypertrophic. The research indicates an advanced and constantly progressive degradation of water quality in Topiło reservoir. Values of TSI (Chl) were in the range of 49.2-77.35 and therefore water status in winter can be defined as eutrophic indicating the hypertrophy in remaining periods under study. Additional investments planned for advance reclamation treatments should be necessarily taken into consideration at the stage of planning and design of new small water retention reservoirs. Topiło reservoir requires modernization and reclamation, it is also necessary to clean it up, especially the bottom pond, out of the stocked wood residues, as well as to remove the excess of sludge.
\end{abstract}

Keywords: small retention reservoirs, trophic state index, biogenic compounds,

\section{INTRODUCTION}

Polish water resources are estimated below the European average. Recently this was the reason for a significant increase in investment in the construction or expansion of small retention reservoirs. However, apart from the amount of retained water, its quality, which determines the ability to use built reservoirs in accordance with their original purpose, is even a more important issue. As a result of filling the natural depressions, water in retention reservoirs accumulates contaminants, in a form of both suspensions as well as in the dissolved or colloidal forms that run down from the direct and indirect catchment [1]. The rate of water flowing through the damming reservoir is substantially slowed as compared to the river, where it is located, which contributes to an increase in primary production, while causing the change in the trophic level of water. According to the definition proposed by Einar Naumann, who was the first in 1929 to use the term trophic level, it is defined as "quantitative phytoplankton production" in relation to the water in lakes $[2,3]$. Since then, 
many researchers took up this issue with consideration to whether primary production refers to the growth of phytoplankton or algae mass, or biomass. Definitions of biomass were varied as "total weight of living organisms" or with emphasis on bio-fuels as "total weight of organic matter, living and dead" [3]. Einar Naumann and August Thienemann, at the turn of 1920's and 1930's, developed distinct concepts of trophic level classification based on an assessment of the level of ecosystem productivity in terms of phytoplankton and species diversity of benthic organisms and oxygen conditions, while Thienemann found that the typology of lakes should be adapted to different climate zones and different temperatures [4, $5,6]$. Currently, the basic indicators commonly used to assess the trophic level are: concentration of chlorophyll "a", total phosphorus, total nitrogen, Secchi depth, turbidity, and aerobic conditions [7]. In 1977, Professor Carlson introduced the concept of trophic state index (TSI) based on measuring the concentration of total phosphorus, chlorophyll "a", and water transparency as Secchi disc visibility [8]. Calculation of the TSI by measuring the Secchi disc visibility and total nitrogen and total phosphorus cause achieving more potential errors than when applying a concentration of chlorophyll "a" [3]. Secchi depth is of limited use as a trophic status index in the case of shallow reservoirs, in which not only the particles of algae floating in the water affect the turbidity [3, 9]. Chlorophylls as photosynthetic pigments occurring in the chloroplasts of plants, algae, and bacteria cells are considered as an important and relatively easy to examine component of the trophic index evaluation of water [10]. Topiło reservoir created in 1932-33 was not subject to any cleaning treatments and thus to define the TSI indicators seemed very interesting in the context of ongoing changes in the trophic status of waters. Assessment of the trophic level of the reservoir functioning for many years, will provide direction of changes occurring in the currently built or modernized small retention reservoirs.

\section{METHODS}

Studies upon the trophic status were carried out using water samples from a small retention reservoir Topiło, located in especially valuable natural forests of Puszcza Białowieska. The reservoir was built in 1932-1933 by damming the flat valley of river Perebel on 4.5 kilometers of its course with the causeway and weir, which allowed for damming by $1.8 \mathrm{~m}$. The reservoir Topiło consists of three connected parts, that in 1933-1976 were used to store trees and wood in water. The investor of the reservoir was the sawmill Hajnówka. Total reservoir capacity is about 250 thousand $\mathrm{m}^{3}$, area $21.1 \mathrm{ha}$, and the average depth is not more than $1.0 \mathrm{~m}$. The reservoir is 1700 $\mathrm{m}$ long and $400 \mathrm{~m}$ wide. It consists of three connected ponds: the upper one of 7.2 ha, the center one of 5.1 ha, and the bottom one of 8.8 ha area.

Water outlet from the reservoir is done by weir, which is embedded in the body of earthen dike. In addition, there are two water damming devices that divide reservoir into ponds: one of them is situated under narrow gauge railway, the other under the bridge on the road Topiło - Łozice. The reservoir bottom is muddy and shores are marshy, making it difficult to access $[11,12]$.

The catchment of Topiło reservoir of about $31.9 \mathrm{~km}^{2}$ lies near the watershed of the rivers Bug and Narew. Water resources of the reservoir come mainly from inflowing river Perebel and the additional inflow from rainfall with average annual amount of $633 \mathrm{~mm}$. Approximately $80 \%$ of the catchment area is covered by forests, mainly mixed forest habitats. Swamp and wetland habitats occupy slightly more than $35 \%$ of the forest area $[13,14]$. Conifers, mainly pines and spruces, cover about $64 \%$ of the whole catchment, and the most common deciduous trees are alder, oak, and birch. Due to increasing share of broadleaved species, an upward trend in water needs of the tree stands has been observed [11].

The original purpose of the reservoir was to store timber that was transported from all over the Puszcza Białowieska. The raw material was stored in water at the lowest point of the bottom pond to protect against insects. Despite the fact that wood was stored in 1979 for the last time, rotting tree trunks can be still seen. The purpose of the reservoir changed and it is now used by anglers, who have a special permit from Forest Inspectorate Hajnówka [11, 12, 13]. Recently, Topiło reservoir has become a place readily visited by tourists thanks to the Forest Tourist Complex, which was established in 1994. This enabled to reactivate narrow gauge railway, that is a tourist attraction of that area. The reservoir is picturesque and unique because of a unique microclimate produced over the years. Surroundings of the reservoir create perfect conditions for ob- 
serving animals, plants, and birds. Bonfires and outdoor meetings can be organized there. In order to assess the degree of Topiło reservoir contamination, three measurement and control points were selected for testing, which were situated near the inflow (point No. 1) and outflow (point No. 3) of the river Perebel, as well as in the middle part of the reservoir (point No. 2). The selection and placement of measurement and control points on the reservoir was dictated by the ability to capture changes in the study object. Tests of water samples collected from the surface layer of the coastal zone, were carried out once a month during the period from April 2007 to March 2014. The following determinations were performed in the collected water samples: total nitrogen, total phosphorus, chlorophyll "a", and turbidity. All tests were carried out in accordance with the current methodology [15, 16]. The level of significance and power of the test assumed in the calculations as a measure of the reliability of the test results. The procedure uses a method of mathematical statistics regarding power analysis tests. The results of calculations are given in Table 1.

The trophic level of Topiło reservoir was also assessed according to the concentration criteria and based on the trophic status indices (TSI) calculated after Carlson's as well as Kratzer and Brezonik's. The trophic indices were calculated according to Carlson TSI (Chl) in $\mu \mathrm{g} / \mathrm{dm}^{3}$, TSI (TP) in $\mathrm{mgP} / \mathrm{dm}^{3}$, according to Kratzer and Brezonik TSI (TN) in $\mathrm{mgN} / \mathrm{dm}^{3}$ (Figure 3). General trophic level of the reservoir TSI was assessed using the achieved mean value from the three calculated indices TSI(Chl), TSI(TP), TSI(TN) and illustrated in Figure 4. Water transparency measured by Secchi disc was skipped, because it is of little importance in the dam reservoirs, when assessing the trophic status. It should be noted that in this type of shallow objects, water movement caused by strong winds leads to mixing of the water and floating suspensions affecting the Secchi depth. Water inflowing during heavy rainfall introduces a large amount of impurities that cause turbidity of retained water. The reduction of induced transparency is not directly related to the growth of phytoplankton $[3,9,17]$. Therefore, we omitted this element of the TSI index (SD) in the present study. Assessment of the trophic level is based on the analysis of the whole set of physical, chemical, biological, and morphological factors. Values of the trophic status indicators by Carlson are as follows: TSI $<40$ oligotrophy, 40-50 mesotrophy, 50-70 eutrophy, $>70$ hypertrophy [8]. Assessment of the eutrophication degree is made on the basis of average annual values of biogenic indicators for flowing waters [18].

\section{RESULTS AND DISCUSSION}

Results of water quality parameters in the Topiło reservoir in 2007-2014 show significant differences (Tables 1-5). During the research, values of the TSI indicator (TN) varied within the range from 69.63 in 2007/2008 to 72.46 in 2013/14 (Figure 4) showing steady growth. This gives a basis for classifying water in the reservoir as hypertrophic. Based on the analysis of determined total nitrogen concentrations, a clear seasonal trend of its occurrence during the entire study period was observed (Tables 2-5, Figure 1). In summer, the total nitrogen concentrations were the lowest and then gradual increase in the value until the peak concentrations achieved in spring, were recorded. During the spring and autumn circulation, a significant increase in turbidity was observed, which could be caused by floating and mixing of sediment particles with water column. Much lower turbidity values recorded in the remaining periods might occur due to sedimentation of suspensions resulting from the decrease in the water flow-rate in the reservoir.

Table 1. The results of the power of the tests in the Topiło reservoir

\begin{tabular}{|c|c|c|c|c|}
\hline \multicolumn{5}{|c|}{ Bachmaty reservoir } \\
\hline Parameters & TN & TP & Chlorophyll & Turbidity \\
\hline The average value of the null hypothesis (Mi0) & 0.00 & 0.00 & 0.00 & 0.00 \\
\hline The average value in the population (Mi) & 4.11 & 1.54 & 17.12 & 45.77 \\
\hline Population standard deviation (Sigma) & 3.22 & 0.89 & 7.13 & 16.60 \\
\hline Standardized Effect (Es) & 1.28 & 1.73 & 2.40 & 2.76 \\
\hline Probability of the I type error (Alfa) & 0.05 & 0.05 & 0.05 & 0.05 \\
\hline Target power & 0.80 & 0.80 & 0.80 & 0.80 \\
\hline The power of required numerical force of sample $\mathrm{N}$ & 0.80 & 0.82 & 0.88 & 0.94 \\
\hline Required numerical force of sample (N) & 7.00 & 5.00 & 4.00 & 4.00 \\
\hline
\end{tabular}


Table 2. Results from Topiło reservoir study carried out in 2007/2008

\begin{tabular}{|c|c|c|c|c|c|c|}
\hline \multicolumn{7}{|c|}{ Topiło IV 2007 - III 2008} \\
\hline Parameter & Unit & $\frac{\min -\max }{\text { average }}$ & $\begin{array}{c}\text { average } \\
\text { Spring }\end{array}$ & $\begin{array}{l}\text { average } \\
\text { Summer }\end{array}$ & $\begin{array}{l}\text { average } \\
\text { Autumn }\end{array}$ & $\begin{array}{c}\text { average } \\
\text { Winter }\end{array}$ \\
\hline Total nitrogen & $\mathrm{mg} \mathrm{N} / \mathrm{dm}^{3}$ & $\frac{0.69-10.21}{3.77}$ & 8.26 & 1.01 & 2.25 & 3.58 \\
\hline Total phosphorus & $\mathrm{mg} \mathrm{P} / \mathrm{dm}^{3}$ & $\frac{0.58-3.03}{1.56}$ & 0.61 & 1.04 & 1.62 & 2.97 \\
\hline Chlorophyll „a” & $\mu \mathrm{g} / \mathrm{dm}^{3}$ & $\frac{6.11-25.18}{17.31}$ & 24.17 & 22.30 & 13.85 & 7.49 \\
\hline Turbidity & NTU & $\frac{15-58}{36.42}$ & 32.33 & 52 & 35.67 & 25.67 \\
\hline
\end{tabular}

Table 3. Results from Topiło reservoir study carried out in 2009/2010

\begin{tabular}{|c|c|c|c|c|c|c|}
\hline \multicolumn{7}{|c|}{ Topiło IV 2009 - III 2010} \\
\hline Parameter & Unit & $\frac{\min -\max }{\text { average }}$ & $\begin{array}{c}\text { average } \\
\text { Spring }\end{array}$ & $\begin{array}{l}\text { average } \\
\text { Summer }\end{array}$ & $\begin{array}{l}\text { average } \\
\text { Autumn }\end{array}$ & $\begin{array}{c}\text { average } \\
\text { Winter }\end{array}$ \\
\hline Total nitrogen & $\mathrm{mg} \mathrm{N} / \mathrm{dm}^{3}$ & $\frac{0.73-11.31}{4.04}$ & 8.84 & 0.93 & 2.46 & 3.91 \\
\hline Total phosphorus & $\mathrm{mg} \mathrm{P} / \mathrm{dm}^{3}$ & $\frac{0.61-2.94}{1.58}$ & 0.64 & 1.01 & 1.75 & 2.9 \\
\hline Chlorophyll „a” & $\mu \mathrm{g} / \mathrm{dm}^{3}$ & $\frac{6.01-26.14}{18.97}$ & 25.84 & 22.82 & 16.12 & 7.35 \\
\hline Turbidity & NTU & $\frac{30-69}{42.58}$ & 40 & 60 & 39.33 & 31 \\
\hline
\end{tabular}

Table 4. Results from Topiło reservoir study carried out in 2011/2012

\begin{tabular}{|c|c|c|c|c|c|c|}
\hline \multicolumn{7}{|c|}{ Topiło IV 2011 - III 2012} \\
\hline Parameter & Unit & $\frac{\min -\max }{\text { average }}$ & $\begin{array}{c}\text { average } \\
\text { Spring }\end{array}$ & $\begin{array}{l}\text { average } \\
\text { Summer }\end{array}$ & $\begin{array}{l}\text { average } \\
\text { Autumn }\end{array}$ & $\begin{array}{c}\text { average } \\
\text { Winter }\end{array}$ \\
\hline Total nitrogen & $\mathrm{mg} \mathrm{N} / \mathrm{dm}^{3}$ & $\frac{0.87-11.02}{4.22}$ & 9.1 & 1.04 & 2.66 & 4.10 \\
\hline Total phosphorus & $\mathrm{mg} \mathrm{P} / \mathrm{dm}^{3}$ & $\frac{0.54-2.81}{1.48}$ & 0.60 & 0.96 & 1.62 & 2.73 \\
\hline Chlorophyll „a” & $\mu \mathrm{g} / \mathrm{dm}^{3}$ & $\frac{5.2-24.21}{18.34}$ & 23.87 & 21.47 & 15.92 & 7.12 \\
\hline Turbidity & NTU & $\frac{30-79}{45.42}$ & 46 & 65.33 & 38.67 & 31.67 \\
\hline
\end{tabular}

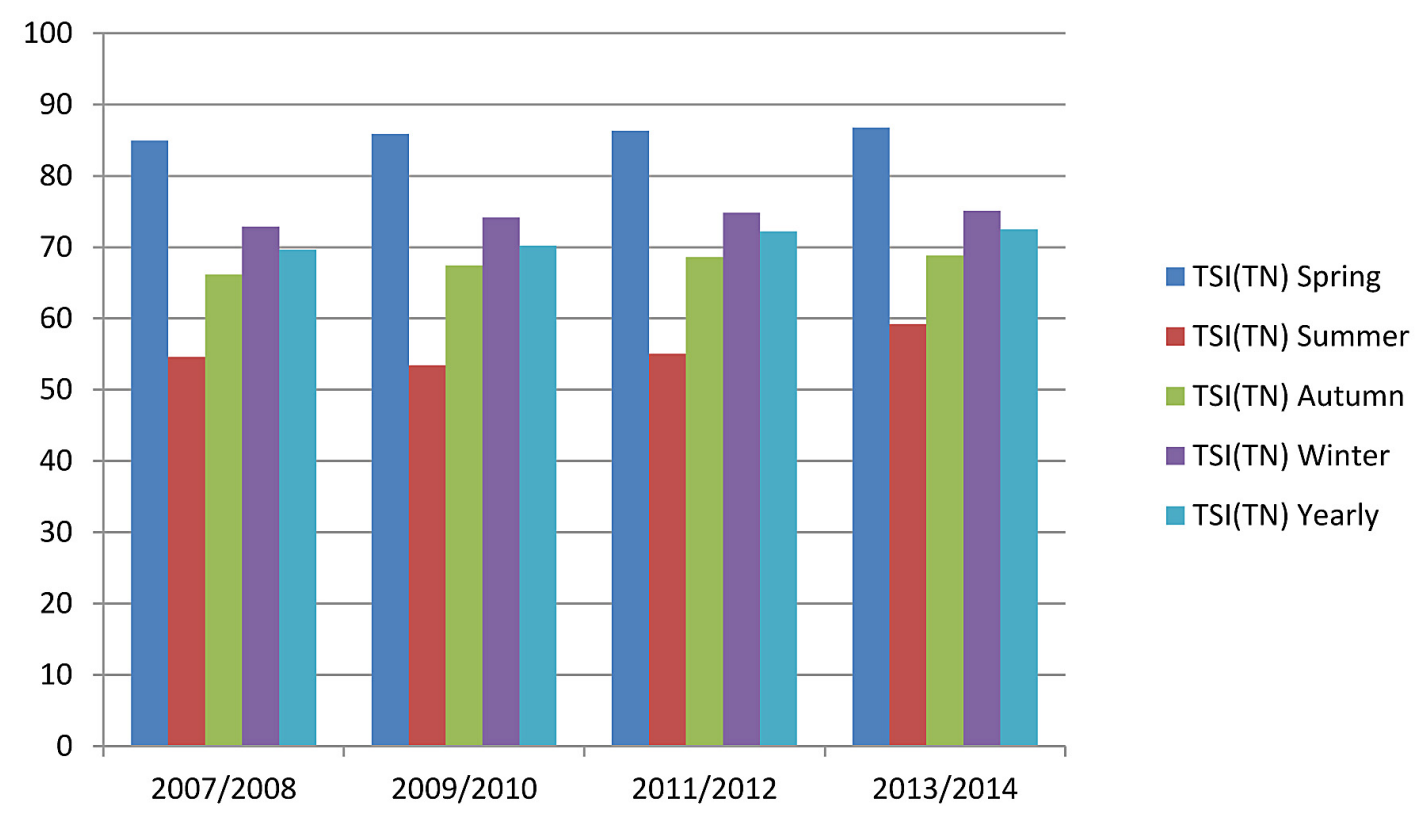

Figure 1. Mean trophic level TSI(TN) of Topiło reservoir in individual seasons and years of study 
After the start of the growing season, biogenic compounds were quickly taken along with the development of biological life, which resulted in intense water blooms observed in the reservoir. Decaying of algae after blooms could affect the increased content of organic substances in water, which leads to oxygen deficiency. As a result of mineralization processes of organic matter contained in bottom sediments, biogenic compounds penetrate the water and the largest amounts of organic nitrogen compounds are released together with ammonium ions. Biogenic substances present in the layer of bottom sediments of the shallow Topiło reservoir could be one of the main factors affecting water quality. The factor controlling the rate of nitrogen transition from sediments into the water column is the content of dissolved oxygen in the bottom layers [1]. Additionally, water turbulence, its stirring caused by the wind and its movement speed, affected the deposits lifting in such a shallow reservoir.
Given the annual average value of overall trophic level (Trophic Status Index) (Figure 4), the dominant role of the TSI (TP) during all years of research attracts some attention. The TSI index values ranged within 78.3-80.26 (Figure 4), which allowed to classify water of Topiło reservoir as hypertrophic. The largest share in that had TSI (TP) value, which in various seasons $(2007 / 08,2009 / 10,2011 / 12$, and 2013/14) amounted respectively to $107.86,108.11,107.2$, and 108.08 always classifying the water as hypertrophic (Figure 4). Shallow reservoirs with similar external trophic load are much more fertile than deep ones [1, 19].

The lowest concentrations of total phosphorus were measured in spring, showing a rising trend until in summer and autumn reaching the maximum values in winter (Tables 1-4), which confirms the literature data $[7,20]$. The phosphate ions are subject to sorption on the surface of suspensions or undergo precipitation and ac-

Table 5. Results from Topiło reservoir study carried out in 2013/2014

\begin{tabular}{|c|c|c|c|c|c|c|}
\hline \multicolumn{7}{|c|}{ Topiło IV 2013 - III 2014} \\
\hline Parameter & Unit & $\frac{\min -\max }{\text { average }}$ & $\begin{array}{c}\text { average } \\
\text { Spring }\end{array}$ & $\begin{array}{l}\text { average } \\
\text { Summer }\end{array}$ & $\begin{array}{l}\text { average } \\
\text { Autumn }\end{array}$ & $\begin{array}{c}\text { average } \\
\text { Winter }\end{array}$ \\
\hline Total nitrogen & $\mathrm{mg} \mathrm{N} / \mathrm{dm}^{3}$ & $\frac{0.79-11.23}{4.42}$ & 9.4 & 1.39 & 2.7 & 4.18 \\
\hline Total phosphorus & $\mathrm{mg} \mathrm{P} / \mathrm{dm}^{3}$ & $\frac{0.59-2.99}{1.55}$ & 0.66 & 1.03 & 1.70 & 2.81 \\
\hline Chlorophyll „a” & $\mu \mathrm{g} / \mathrm{dm}^{3}$ & $\frac{5.3-25.06}{18.68}$ & 24.74 & 21.54 & 16.32 & 6.69 \\
\hline Turbidity & NTU & $\frac{40-112}{58.67}$ & 57.33 & 83.33 & 48.67 & 45.33 \\
\hline
\end{tabular}

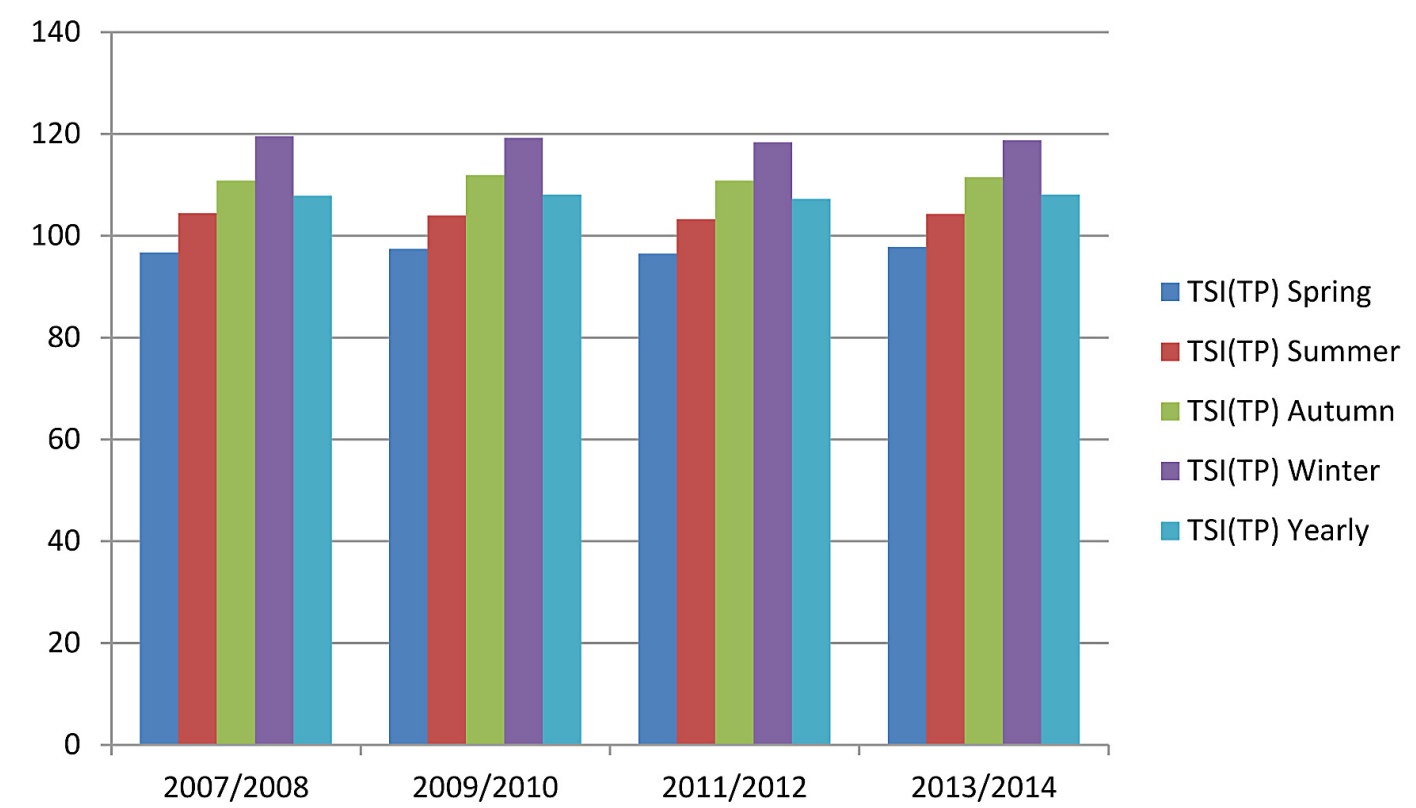

Figure 2. Mean trophic level TSI(TP) of Topiło reservoir in individual seasons and years of study 
cumulation as insoluble compounds on the bottom of the reservoir. Phosphorus present in such a form is not available for aquatic vegetation [21]. Water circulation, the effect of which is mixing the above-sediment with surface layers, is an important factor determining the increase in the content of phosphorus in autumn. Processes of phosphorus exchange between water and bottom sediments are faster at higher temperatures and thus during the year, a systematic slow increase in total phosphorus concentration was recorded in the analyzed samples. On the other hand, anaerobic conditions favor significantly faster release of phosphates into the water column than aerobic ones. As it is well known, the areas of Puszcza Białowieska, where the studied reservoir is located, is characterized by particularly low temperatures in winter, which is the reason for the existence of ice cover preventing the atmospheric oxygen dissolution and promoting formation of oxygen deficiency. In addition, lack of vegetation during this period explains the greatest concentrations of total phosphorus during winters.

Evaluation of the trophic status is based on determining the chlorophyll concentration, because it is specific for the algae and can be used to measure the abundance of their growth even in the presence of an excess of organic and inor-

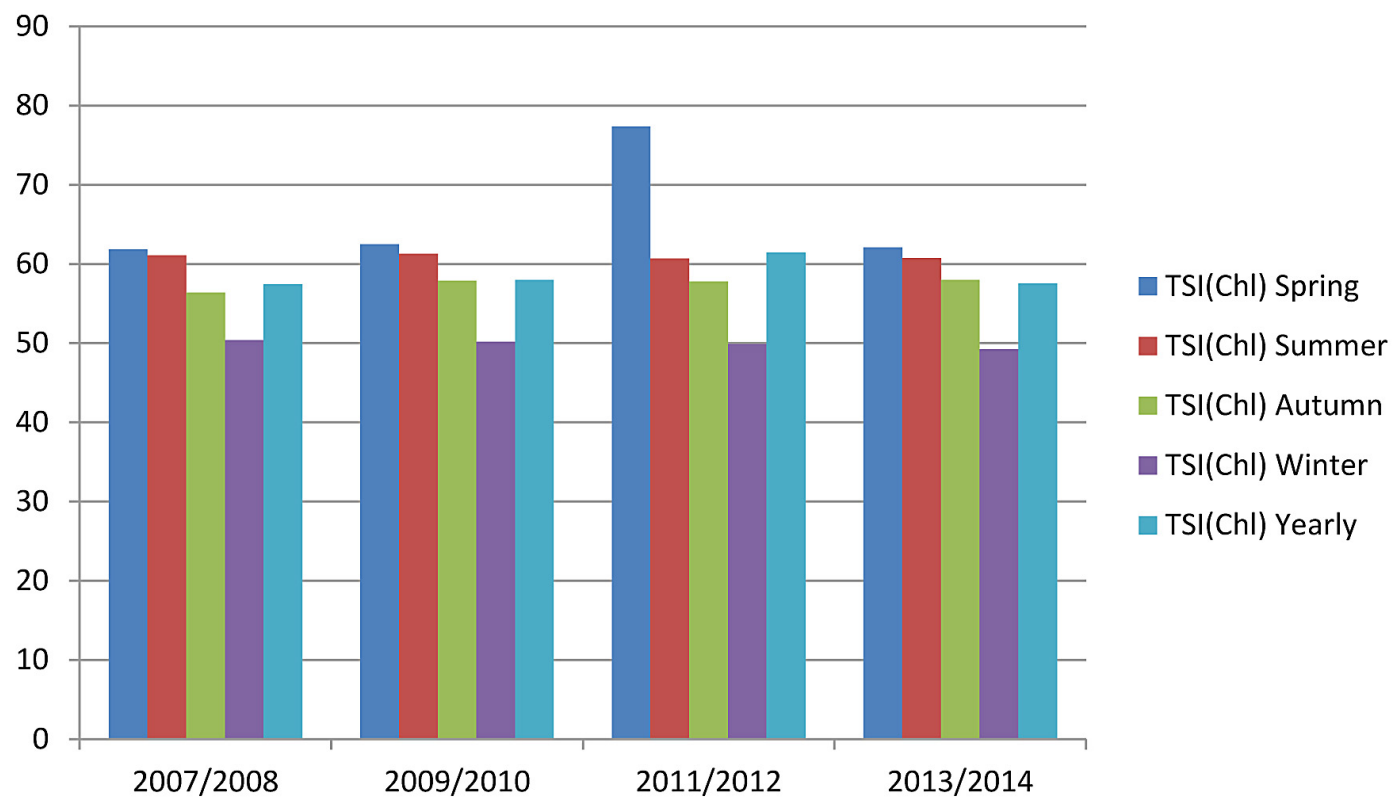

Figure 3. Mean trophic level TSI(Chl) of Topiło reservoir in individual seasons and years of study

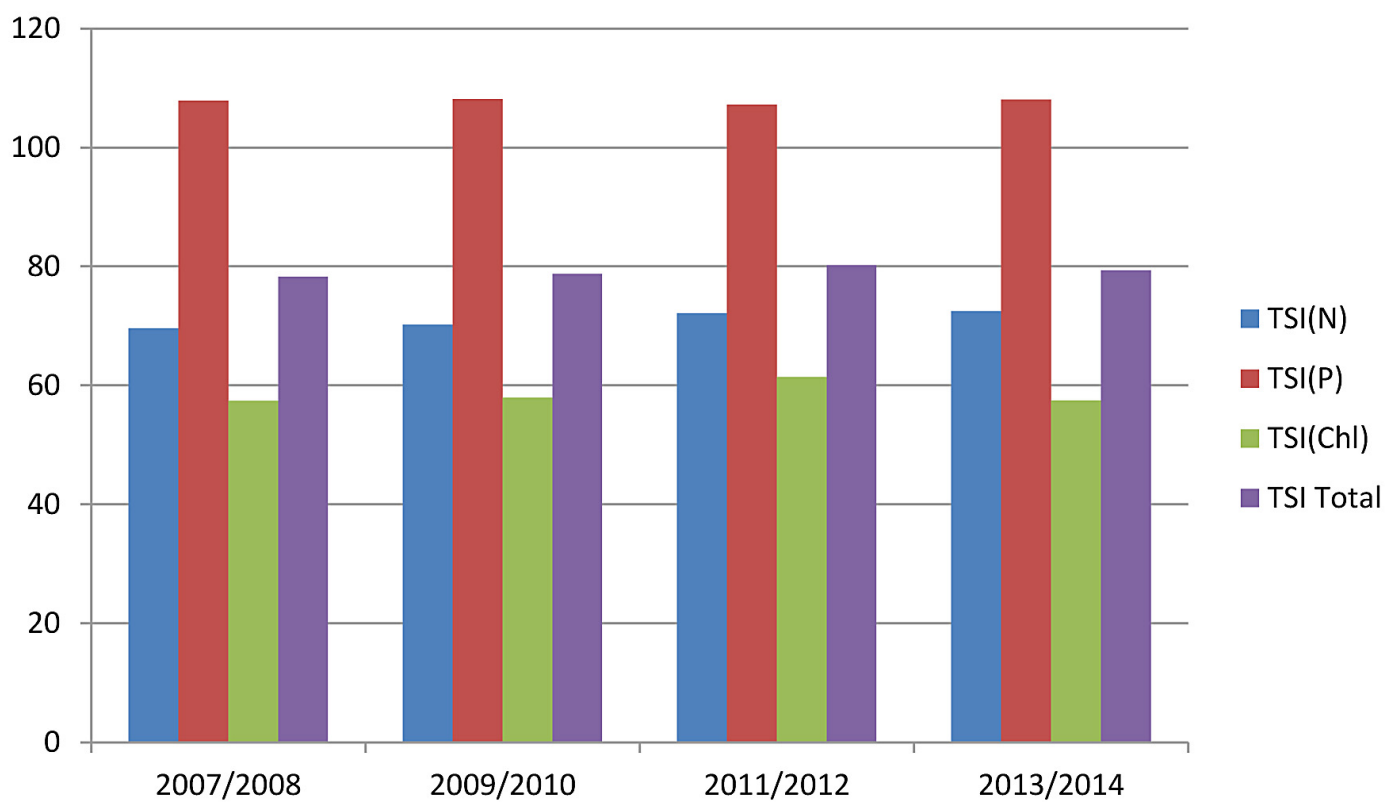

Figure 4. Annual average trophic level of Topiło reservoir in individual years of study 
ganic particles. Concentrations of chlorophyll "a" ranged from $5.2 \mu \mathrm{g} / \mathrm{dm}^{3}$ to $26.14 \mu \mathrm{g} / \mathrm{dm}^{3}$ (Tables 2-5). The highest concentrations of chlorophyll "a" were determined during studies conducted in spring and summer, and winter seasons were characterized by significantly lower values (Figure 3). The water color affects its transparency, but does not influence chlorophyll-phosphorus relations. Turbidity of water due to the growth of algae usually affects both transparency and concentration of total phosphorus, while total nitrogen remains less affected [3]. Carlson suggests that the determination of chlorophyll to estimate the weight of algae should be used as a primary index $[3,8,21]$. Calculated values of TSI (Chl) were within the range of 49.2-77.35 and only in winter their status was defined as eutrophic indicating hypertrophy at other times. The condition favorable for intensive development of phytoplankton in waters of the Topiło reservoir is undoubtedly its small depth.

Precipitation is the main source of water in forest ecosystems and due to water retaining, the proper role of humid and swampy habitats can be restored. Adverse effects of drying can be inhibited by collecting water in retention reservoirs as a result of stopping its outflow from the catchment area. Topilo reservoir will still be able to effectively play those functions only if modernization or reconstruction of dams is performed or reclamation of the reservoir is made. It is also necessary to clean, especially the bottom pond, out of stocked wood residues as well as to remove the excess of sludge mudding the entire reservoir. These activities will contribute to the protection of aquatic ecosystem and preserve the attractiveness of the reservoir.

\section{CONCLUSIONS}

1. The research indicate an advanced and constantly progressive degradation of water quality in Topiło reservoir.

2. Very high concentrations of total nitrogen and phosphorus in water could result from the storage of sawmill wood over 30 years ago and large accumulations of organic matter in bottom sediments leading to the secondary water contamination.

3. Values of calculated indicators TSI $(\mathrm{TN})$ and TSI (TP) allow to classify the Topiło reservoir as hypertrophic.
4. Values of TSI (Chl) were in the range of 49.277.35 and therefore, the water status in winter can be defined as eutrophic indicating the hypertrophy in remaining periods under study.

5. Additional investments planned for advance reclamation treatments should be necessarily taken into consideration at the stage of planning and design of new small water retention reservoirs.

6. Topiło reservoir requires modernization and reclamation, it is also necessary to clean it up, especially the bottom pond, out of the stocked wood residues, as well as to remove the excess of sludge.

\section{REFERENCES}

1. Kajak Z., 2001. Hydrologia-limnologia. Ekosystemy wód śródlądowych. Wyd. Naukowe PWN. Warszawa, pp. 362.

2. Naumann E., 1929. The scope and chief problems of regional limnology. Int. Revue ges. Hydrobiol., 21, 423.

3. Carlson R.E., 2007. Estiamting trophic state. Lakeline, Spring, 25-28.

4. Naumann E., 1932. Grundzuge der regionalen Limnologie. Die Binnengewasser, no. 11.

5. Thienemann A., 1921. Seetypen. Naturwissenschaften, no. 18, 1-3.

6. Szatyłowicz E., Siemieniuk A., 2014. Przegląd metod oceny stanu troficznego wód powierzchniowych. Inżynieria Środowiska - Młodym Okiem, vol. 4 Wody powierzchniowe i podziemne, Oficyna Wydawnicza Politechniki Białostockiej, 119-151.

7. Szczykowska J., Siemieniuk A., Wiater J., 2015. Operating difficulties of small water reservoir located in Wasilkow. Journal of Ecological Engineering, 16 (1), 122-126.

8. Carlson R.E., 1977. A tropic state index for lakes. Limnology and Oceanography, 22.

9. Szczykowska J., Siemieniuk A., 2014. The present condition of small retention reservoir and the prospects of its development using the example of the Podlaskie Voivodeship. Journal of Ecological Engineering, 15 (3), 90-96.

10. Carlson R.E., Simpson J., 1996. A coordinator's guide to volunteer lake monitoring methods. North American Lake Management Society, pp. 96.

11. Unpublished materials rendered in Hajnówka Forest District.

12. Zachaj J. 2007. Dawne wodne magazyny drewna. Gazeta Hajnowska, 122, 18. 
13. Sokołowski A.W., 2004. Lasy Puszczy Białowieskiej. Centrum informacyjne Lasów Państwowych, Warszawa, p. 5.

14. Sokołowski A.W., 2006. Przyroda województwa podlaskiego i jej ochrona. Łomżyńskie Towarzystwo Naukowe im. Wagów, Łomża, 11-15.

15. Hermanowicz W. et al. 1999. Fizyczno-chemiczne badanie wody i ścieków. Wydawnictwo Arkady, Warszawa.

16. PN-86-C-05560/02. Woda i ścieki. Badania zawartości chlorofilu w wodach powierzchniowych. Oznaczanie chlorofilu alfa w glonach planktonowych metodą spektrofotometryczną monochromatyczną z poprawką na feopigmenty alfa.

17. Szczykowska J., Siemieniuk A., Wiater J. 2013. Sezonowe zmiany stanu troficznego zbiorników retencyjnych. Ekonomia i Środowisko, 2, 107-116.
18. Rozporządzenie Ministra Środowiska z dnia 23 grudnia 2002 r. w sprawie kryteriów wyznaczania wód wrażliwych na zanieczyszczenia związkami azotu ze źródeł rolniczych. Dz.U. 2002 r. Nr 241, poz. 2093.

19. Szczykowska J., Siemieniuk A., 2009. Analiza czynników determinujących jakość wód wybranych zbiorników małej retencji na Podlasiu. Ochrona Środowiska i Zasobów Naturalnych, 40, 483-490.

20. Wetzel R.G. 2001. Limnology lake and river ecosystem. Academic Press, USA, 205-220.

21. Carlson R.E. 1992. Expanding the trophic state concept to identify non-nutrient limited lakes and reservoirs. Prcedings of a National Conference on Enhancing the States' Lake Management Programs, Monitoring and Lake Impact Assessment. Chicago, 59-71. 